SOMETIMES ALWAYS TRUE 



\section{SOMETIMES ALWAYS TRUE}

Undogmatic Pluralism in Politics, Metaphysics, and Epistemology

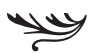

Jeremy Barris

Fordham University Press

New York 20I5 


\section{Copyright (C) 2015 Fordham University Press}

All rights reserved. No part of this publication may be reproduced, stored in a retrieval system, or transmitted in any form or by any means-electronic, mechanical, photocopy, recording, or any other-except for brief quotations in printed reviews, without the prior permission of the publisher.

Fordham University Press has no responsibility for the persistence or accuracy of URLs for external or third-party Internet websites referred to in this publication and does not guarantee that any content on such websites is, or will remain, accurate or appropriate.

Fordham University Press also publishes its books in a variety of electronic formats. Some content that appears in print may not be available in electronic books.

Library of Congress Cataloging-in-Publication Data

Barris, Jeremy.

Sometimes always true : undogmatic pluralism in politics, metaphysics, and epistemology / Jeremy Barris. - First edition.

pages $\mathrm{cm}$

Includes bibliographical references and index.

ISBN 978-0-8232-62I4-4 (cloth : alk. paper)

I. Pluralism. I. Title.

$$
\begin{aligned}
& \mathrm{BD}_{394 . B_{2} 62 \mathrm{I} 4} \\
& \text { I IO- dc23 }
\end{aligned}
$$

Printed in the United States of America

$\begin{array}{llllllll}\text { I7 } & \text { I6 } & \text { I5 } & 5 & 4 & 3 & 2 & \text { I }\end{array}$

First edition 